INTERNATIONAL HIGHER EDUCATION NO. 69 FALL 2012

\title{
How Post-Soviet Russian Academia Struggles with the Past
}

\author{
GREGORY ANDROUSHCHAK and MARIA YUDKEVICH
}

\begin{abstract}
Gregory Androushchak is adviser to the rector, at the National Research University-Higher School of Economics. E-mail: gandroushchak@gmail.com. Maria Yudkevich is vice-rector, at the National Research University-Higher School of Economics. E-mail: yudkevich@hse.ru.
\end{abstract}

Why are faculty contracts and practices in post-Soviet universities (even including research ones) focused on teaching and omit the research part of faculty life? While the historical aspects that caused such a focus are no longer valid, these contracts are now supported by a deeply rooted funding modelbased on the existence of all public universities in Russia. This example is interrelated with socioeconomic institutions that emerged during recent years. Thus, a policy to move toward more-effective contract practices will create a substantial challenge for the higher education system in Russia, which, however, is the only way to improve the overall performance of Russian universities.

\section{How the Past Planning Legacy Affects Today's Life}

For many decades, Soviet universities were funded on the key principle of the Soviet economy-that is, the plan. The central planning agency (the Gosplan) published an insight of what the economy should produce to compete for leadership in all of the conceivable areas; and the ministries estimated the 
number of employees needed by occupation and qualification. The latter principle was used to calculate the number of students in various educational institutions, including vocational schools-institutions of secondary professional training, somewhat similar to the US two-year colleges and universities.

Although the Soviet system has long gone, the former approach has been used until recently in many post-Soviet countries-except for the Gosplan's central planning agency being replaced by the "perspective needs for highqualified personnel," which the university sector has to fulfill. In these circumstances, the nature of student admissions by the academic merit in the Soviet times was mainly what the comrades and observers in the West should believe in—rather than what was really occurring. Experienced former university officials provide quite conclusive evidence that the admissions system was cynically designed just to cut off the necessary number of university applicants, rather than to compete for the best. That competition did not enter the funding formula, in any way; the most important criterion for public funding was just the head count. Moreover, universities that do not admit as many applicants, as planned for them, face cuts of publicly funded places in subsequent years, resulting in reductions of their prospective funding.

Since 1992, universities were allowed to teach students above the publicly funded student body. Naturally, the former had to pay. However, the quest for higher education was so high among Russian youths that their only goal was to enter a university, rather than to seek for good education in a desired field. That meant that competition for stud

Thus, universities lost incentives to attract and employ the best possible faculty. Primarily, due to lack of incentives to sustain and improve teaching 
quality, the economic turmoil of the 1990s was exacerbated by lack of financial resources received from the country for each student.

\section{GETTING Even WORSE?}

The end of the 1990s brought about yet another disaster onto Russian universities. The economic crises of 1991 to 1993 and 1998 virtually destroyed the economy, leaving most of the employment opportunities in oil and gas extraction and retail. However, given the clumsy planning of public funding for disciplines, universities still thought they should focus on educating engineers. Therefore, when searching real jobs, most graduates found few opportunities to apply for work based on what they had been taught. Thus, many students, especially in large cities, meeting no match between their studies and jobs became demotivated. This situation has developed an amazing impotence of the universities, which could not compete either for students or faculty. In the late 1930s, faculty were spared the research function held by the Academy of Sciences.

Hence, many universities primarily become educational entities, built around teaching and learning processes. Thus, faculty contracts explicitly describe teaching loads and obligations. At the same time, the professoriate in general has little incentives and opportunities to actively involve in research: research is poorly rewarded and teaching loads are heavy.

While little room is left for science, research productivity-such as, publications, participation in conferences, etc.--per faculty is considered of great importance for assessing the performance of individual faculty and of whole universities. However, the procedure of internal publications (published by 
departments or universities, without any peer review) is useless as a means of external evaluation of research quality and performance of faculty.

The absence of mechanisms for external evaluation of faculty performance has reduced academic mobility. Faculty became closely tied to their universities and chose to make university-specific investments, which would have little relevance in other places. During the initial stages of their academic careers, faculty focus on producing publications and after acquiring academic credentials turn to securing administrative positions, which both guarantee higher salaries and a certain degree of employment security. As a result, most universities are governed by internal hierarchical bureaucracy, with the academic community playing a minor role in the decision making.

\section{What Could Be Done?}

Overall, public-funding mechanisms play a decisive impact on most of the spheres of university life-including faculty contracts and research and teaching outcomes. Hopefully, during the next few years, the situation of university competition will improve, for which there are already positive signs and premises. First, evidence exists of saturation of the market of higher education. In 2008, the proportion of high school graduates entering universities in Russia reached about 80 percent. The demand shifts from merely entering any university, to entering a particular university and a field of studies. Such conscious applicants constitute no less than a quarter of high school graduates. Second, Russia is witnessing a tremendous decrease of the 17-18-year-old population, which is the primary source of university applicants. Finally, what is really important, the contraction of the number of perspective students is a faster 
prospect than that of the publicly funded places at the universities. That characteristic forces universities to compete for students.

The wisest university leaders have already identified the challenge and develop marketing strategies that point out advantages of their programs to students-mainly, the quality of faculty and provided education, overall. To improve quality, universities need proper conditions-both monetary and nonmonetary ones-to attract productive and dedicated faculty to universities and to restore the academic environment.

How can that be done? First, the Gosplan central planning agency system of university admissions should be reformed. Government money should follow students but should not be distributed without respect to university quality. Second, research functions at strong universities should be restored. During the recent years, the Russian Ministry of Education and Science has launched a number of competitive grant programs for universities-supporting basic science, developing collaboration with industry, and other sectors. Third, the academic system should somehow be shaken up by taking steps to full-fledged participation in the international academic market and engaging in international faculty recruiting.

Nevertheless, faculty contracts are the key element for success. While the current contracts in many post-Soviet countries still reflect the old legacy, given the need for upgrading, prerequisites and signs of improvement are under way. 